\title{
Does the Beige Book Move Financial Markets?
}

\author{
Madeline Zavodny* and Donna K. Ginther $\dagger$
}

\begin{abstract}
About two weeks prior to each Federal Open Market Committee (FOMC) meeting, the Federal Reserve releases a description of economic activity in a document called the Beige Book. By creating a quantitative index of these qualitative reports, we examine whether the content of the Beige Book affects asset prices. The results indicate that more positive Beige Book reports on economic growth are associated with increases in interest rates, particularly intermediate- and long-term rates, but not after controlling for several other macroeconomic indicators. The results are consistent with markets viewing the report as a summary indicator of economic growth but not of monetary policy moves in the near term.
\end{abstract}

JEL Classification: E5, E44

\section{Introduction}

A number of studies indicate that macroeconomic data releases cause movement in a number of financial instruments, including interest rates, stocks prices, and exchange rates (Andersen et al. 2003; Flannery and Protopapadakis 2002; McQueen and Roley 1993). Financial markets also respond to changes in monetary policy via the federal funds rate target (Balduzzi, Bertola, and Foresi 1997). However, little is known about how, or even whether, financial markets systematically respond to qualitative, or nonnumerical, information, such as speeches by Federal Reserve and government officials and nonquantitative economic reports.

Casual empiricism on the part of members of the media leads them to frequently attribute changes in financial markets to qualitative information released by the Federal Reserve. One such qualitative report is the Beige Book, which is a description of economic activity compiled by the 12 regional Federal Reserve banks and released about two weeks before each meeting of the Federal Open Market Committee (FOMC). The media often reports that markets moved in response to the information contained in the Beige Book, with headlines such as "Russell 2000 Retreats After Release of Beige Book" and "Bond Prices Are Lifted by the Fed's Beige Book."1 This paper examines whether the Beige Book indeed affects stock prices and interest rates.

* Agnes Scott College, 141 E. College Avenue, Decatur, GA 30030, USA; E-mail mzavodny@agnesscott.edu; corresponding author.

$\dagger$ University of Kansas, Department of Economics, Summerfield Hall, Lawrence, KS 66045, USA; E-mail dginther@ku.edu.

We thank Li Zhou for research assistance and Rob Bliss, Bob Eisenbeis, Mark Kamstra, Lisa Kramer, Will Roberds, Paula Tkac, Craig Hakkio, Sharon Kozicki, John Robertson, and seminar participants at the University of Kansas and the Federal Reserve Bank of Kansas City for helpful conversations. We also thank Nathan Balke and Mine Yucel for providing the Federal Reserve Bank of Dallas's Beige Book index scores and David R. Payne for providing his scores and helpful comments. This study commenced while both authors were at the Federal Reserve Bank of Atlanta. The opinions expressed here are our own and do not reflect those of the Federal Reserve Bank of Atlanta or the Federal Reserve System.

Received November 2003; accepted January 2005.

${ }^{1}$ Bauman (1995) and Hurtado (1994), respectively. 
There are several reasons why the release of the Beige Book might influence financial markets. First, several studies show that the Beige Book is a good indicator of economic activity. Balke and Petersen (2002) conclude that the Beige Book is a significant predictor of both current and nextquarter real gross domestic product (GDP), even above and beyond other contemporaneous indicators such as the Blue Chip Consensus Forecast and lags of the growth rates of real GDP, industrial production, and employment. ${ }^{2}$ Payne (2001) similarly finds that the Beige Book is well correlated with a variety of economic indicators, including the change in indexes of coincident and leading indicators, the unemployment rate, and capacity utilization. ${ }^{3}$ Given the long lags in the release of some data series, the Beige Book may reflect information not yet available via other sources and thereby affect financial markets.

Even if the report does not contain any new information, financial markets might view the Beige Book as a useful summary of economic activity leading into FOMC meetings. Unlike other data series, the timing of the information gathering and the release date are explicitly geared to the FOMC meetings, which occur eight times a year. Comments from Federal Reserve officials indicate that they rely in part on the Beige Book for such reasons when making policy decisions. For example, FOMC chairman Alan Greenspan reportedly likes the anecdotal information contained in the Beige Book because it provides firsthand insights into the economy in advance of the FOMC meetings (McTague 1991).

In addition, the Beige Book might affect financial markets if the report signals the likely direction of monetary policy. A strong Beige Book report might indicate that the FOMC is likely to tighten monetary policy at its next meeting, while a weak Beige Book might suggest that the FOMC will ease monetary policy. Because the research staffs that advise monetary policy makers have input into the report, the Beige Book may reflect their perceptions and preferred course of policy. Payne (2001) finds that the Beige Book is a significant predictor of changes in the federal funds rate target, outperforming the output gap in a Taylor rule model.

Examining the effect of the Beige Book on financial markets allows us to evaluate whether qualitative information on economic activity affects financial markets in the same way as releases of quantitative macroeconomic data. Although many researchers have examined the impact of data releases, few have examined the effect of qualitative reports because such studies face several hurdles. In studies of data releases, the "news" is relatively easy to determine because the data are released on a regular schedule and at a particular time of day. Researchers typically examine the surprise component of such data releases by taking the difference between the announced value and the average of expected values. In contrast, "headline news," such as speeches about the economy by Greenspan, happens at irregular intervals and may prove difficult to identify and quantify. In addition, expectations about such reports are, at best, difficult to ascertain.

A few previous studies have examined the effect of qualitative reports on financial markets. Most notably, Kohn and Sack (2003) examine the effect of FOMC statements and Congressional testimony and major speeches by Greenspan, focusing on whether financial instruments were more volatile on event days, not on whether and how the actual content of such statements affected asset prices. Kohn and Sack find that FOMC statements and Congressional testimony by Greenspan increase the

\footnotetext{
${ }^{2}$ Fettig, Rolnick, and Runkle (1999), in contrast, find that the Beige Book summaries do not have predictive value beyond that of private sector forecasts. Balke and Yucel (2000) attribute the conflicting results to differences in the timing of the other forecasts used by Balke and Petersen (2002) and by Fettig, Rolnick, and Runkle. Fettig, Rolnick, and Runkle used forecasts made later in the quarter than the Beige Books, whereas Balke and Petersen focused on forecasts released prior to or at the same time as the Beige Books. Footnote 1 in Balke and Yucel (2000) provides a more detailed discussion.

${ }^{3}$ Related studies find that the district Beige Books are well correlated with indicators of regional economic activity (Balke and Yucel 2000; Ginther and Zavodny 2001).
} 
volatility of financial instruments, but major speeches by Greenspan do not. Other studies suggest that the quantity of financial news reported by the media is correlated with stock market returns and trading volume (Berry and Howe 1994; Mitchell and Mulherin 1994). We are not aware of any previous research that links the actual content of qualitative news to changes in financial markets.

The next section briefly describes the Beige Book and offers economic intuition for why the report might influence financial instruments. We then explain the quantitative index of the Beige Book that we created in order to investigate whether the reports are associated with changes in several measures of interest rates and equity prices during the period mid-1983 to 2001 . The results indicate that the qualitative information contained in the Beige Book is associated with changes in some financial markets, mainly intermediate- and long-term interest rates. Controlling for available data on GDP growth or industrial production suggests that markets view the Beige Book as a summary indicator of recent economic growth.

\section{Description of the Beige Book}

The Beige Book is a survey of regional economic conditions publicly released about two weeks prior to each FOMC meeting since mid-1983. ${ }^{4}$ Each of the 12 regional banks writes a summary of economic conditions in its district, and one bank (on a rotating basis) writes a summary of national economic conditions based on the 12 regional reports. The research staff at the Board of Governors does not write the regional reports or the national summary but does have input into the wording of the document, particularly the national summary.

Each Federal Reserve Bank uses its own information-gathering methods to compile its Beige Book report. Most districts use a variety of methods, including calling local businesses, conducting regular surveys, reading local newspapers, and having members of their Boards of Directors report on current and expected future economic conditions. The regional banks tend to emphasize those sectors that are economically important in the various districts, as well as recent major economic developments. The reports focus on economic conditions since the last FOMC meeting, essentially the last four to six weeks. Although the reports sometimes include details about future expectations, the Beige Book primarily discusses contemporaneous conditions and recent events.

\section{Quantifying the Beige Book}

In order to examine the effect of the content of the Beige Book on financial markets, the qualitative reports need to be quantified. Because the Beige Book is anecdotal, the reports describe the pace of economic activity with adjectives such as strong, moderate, or weak. Following the method of Balke and Petersen (2002), we created a quantitative index of these qualitative descriptions. We recreated Balke and Petersen's index in order to evaluate whether it is possible to derive consistent quantitative measures of the qualitative accounts in the Beige Book, as well as to update it. We read each Beige Book (without knowing the release date) released between May 1983 and December 2001 and scored the description of economic growth in the national summary on a scale from -2 to 2 , with lower scores indicating weaker growth. A Beige Book describing modest growth typically was scored

\footnotetext{
${ }^{4}$ Before May 1983, the Beige Book was confidential within the Federal Reserve System and was called the Red Book. Our sample period begins with the Beige Book released on May 18, 1983. We drop the report dated as released on September 16, 1984, from the sample since this date was during a weekend, making the actual release date suspect.
} 


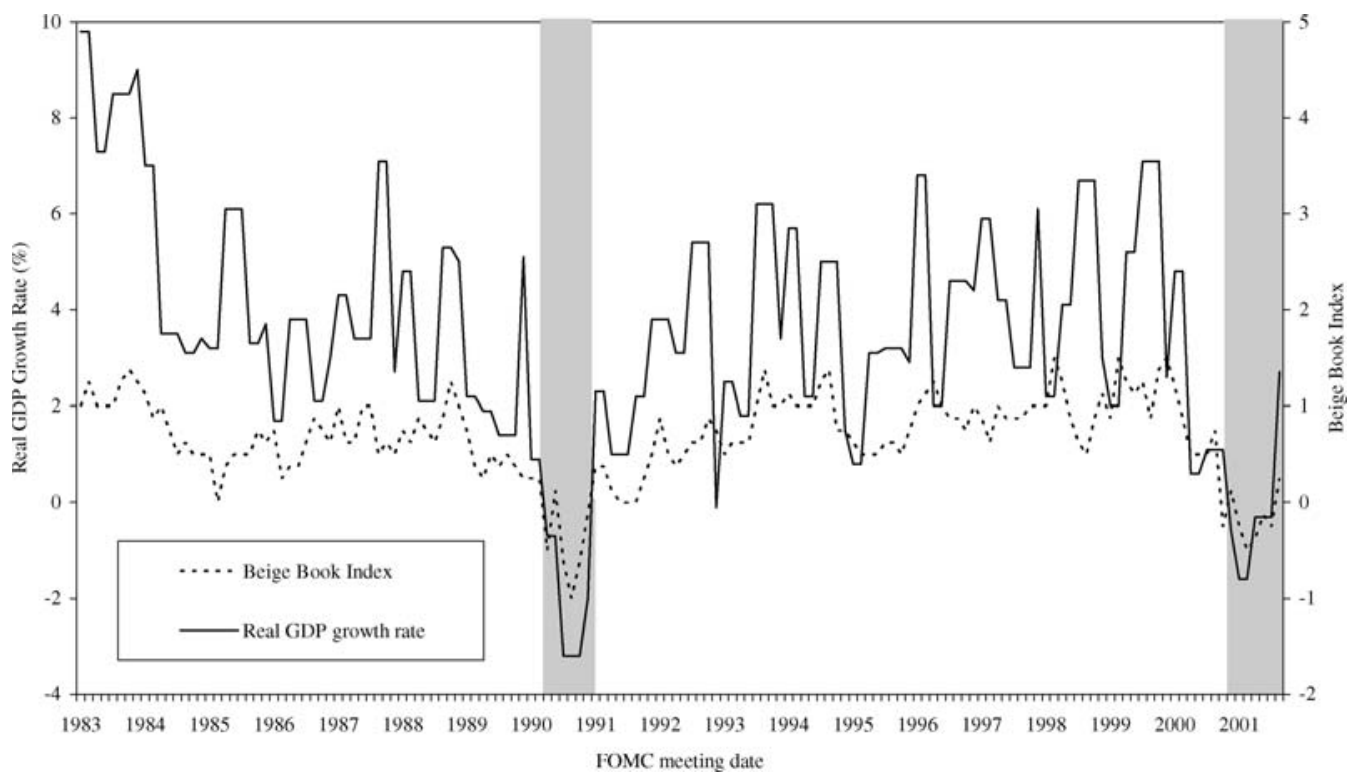

Figure 1. Beige Book Index and GDP Growth. Shaded areas indicate recessions

0.5; a Beige Book describing strong growth received a score of 1 to 1.5; a Beige Book that indicated that activity was contracting received a negative score. Although key adjectives were helpful in determining the Beige Book score, we did not solely rely upon them. Instead, we used our judgment in much the same way financial market participants would. This analysis uses the average of our two scores for the national summary. ${ }^{5}$ The strong correlation between our scores and Balke and Petersen's scores $(\rho=0.94)$ during the period they overlap (1983-1996) suggests that such indexes can be replicated fairly reliably.

Our Beige Book index is well correlated with the pace of economic activity. As Figure 1 indicates, the index tends to be high during times of strong GDP growth and negative during recessions (the shaded areas). The raw correlation between our Beige Book index and real currentquarter GDP growth is 0.672 . To further investigate whether our index is well correlated with output growth, we regressed real GDP growth rates on the index using Balke and Petersen's (2002) methodology. Table 1 reports the results for our index and for Balke and Petersen's index. Our index is as well correlated with GDP growth through 1996, as is Balke and Petersen's index (columns 1 and 2). Including the 1997-2001 period slightly reduces the goodness of fit of our index as measured by the adjusted $R^{2}$, but the relationship remains positive and statistically significant (column 3).

The Beige Book index also appears to be correlated with trends in monetary policy. Figure 2 shows the Beige Book score associated with each FOMC meeting from mid-1983 to 2001 and the discount rate and federal funds rate target decided on at that meeting. The index appears to generally track changes in the federal funds rate target and the discount rate. During the early 1990s, however, there is no clear relationship between the index and the targets, with the rise in our Beige Book index

\footnotetext{
${ }^{5}$ We focus on the national summary instead of the individual district reports because financial markets are more likely to react to the national summary. We use the average of our two scores in order to reduce measurement error. Using either of the authors' scores yields results similar to those shown here. Using Balke and Petersen's scores for 1983-1996 in our regression models also gives similar results to using our scores for the same period.
} 
Table 1. Relationship between Beige Book Indexes and Real GDP Growth Rate

\begin{tabular}{lccc}
\hline & Balke \& Petersen $5 / 83-12 / 96$ & Our Index $5 / 83-12 / 96$ & Our Index 5/83-12/01 \\
& $(1)$ & $(2)$ & $(3)$ \\
\hline Beige Book index & $3.992^{* * *}(0.431)$ & $4.255^{* * *}(0.385)$ & $3.750^{* * *}(0.346)$ \\
Constant & $0.887 * * *(0.286)$ & $0.828^{* * *}(0.247)$ & $0.987 * * *(0.225)$ \\
Adj. $R^{2}$ & 0.456 & 0.502 & 0.451 \\
$N$ & 108 & 108 & 149 \\
\hline
\end{tabular}

Shown are coefficients (standard errors) from OLS regressions with the current-quarter real GDP growth rate as the dependent variable. Standard errors are White-corrected for heteroscedasticity.

$* p<0.10 ; * * p<0.05 ; * * * p<0.01$.

preceding the increases in the federal funds rate target and the discount rate by several years. This is not surprising given that the Federal Reserve purposely maintained a relatively loose monetary policy after the recession until 1994 (Greenspan 1994). A similar pattern appears during the 2001 recession, with the Beige Book index strengthening while the FOMC continued to cut rates.

\section{Why the Beige Book Might Affect Markets}

The Beige Book could affect financial markets through several channels. First, as discussed above, the Beige Book may reflect the future direction of monetary policy. If the Beige Book reveals new information about the likely future stance of the FOMC, higher Beige Book scores should be positively associated with changes in nominal interest rates and negatively associated with stock returns. In addition, because moves in short-term interest rates tend to more closely track changes in the federal funds rate than do long-term rates, the effect on interest rates should be more pronounced at the short end of the yield curve if markets interpret the Beige Book as a signal of whether the FOMC will change the federal funds rate target at the next meeting or two. This might be the case if markets view the Beige Book as providing new information about the Federal Reserve's perceptions of economic growth and inflationary pressures that would, in turn, influence monetary policy.

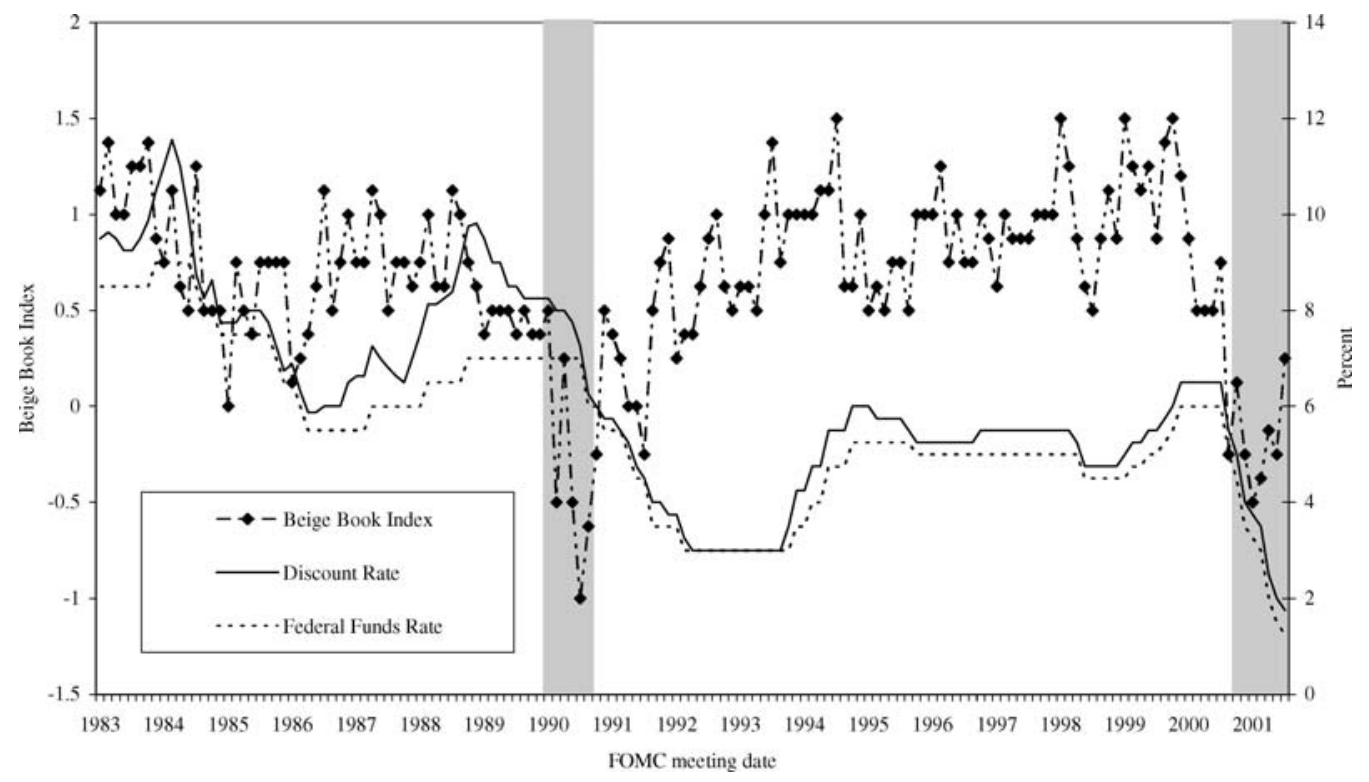

Figure 2. Beige Book Index and Monetary Policy Decisions 
However, the Beige Book might affect long-term rates as well. Several studies suggest that changes in monetary policy can have substantial effects on long-term rates. Campbell (1995) notes that long-term rates have occasionally moved more in response to monetary policy changes than have shortterm rates. He speculates that long-term rates might be more responsive to FOMC interest-rate hikes when the term premium rises due to increased interest-rate risk, bond-market volatility, or increased uncertainty about Federal Reserve policy. Kuttner (2001) finds that unanticipated changes in the federal funds rate target are associated with slightly larger changes in intermediate-term rates than in the 3 month rate; he also finds significant effects on long-term rates. Kohn and Sack (2003) report that Congressional testimony by Greenspan has a larger effect on the volatility of intermediate-term rates than on the volatility of short-term rates. Balduzzi, Elton, and Green (2001) find that longer-term rates respond more to several macroeconomic data series, such as Consumer Price Index (CPI), GDP, and housing data, than do shorter-term rates; long-term rates may respond to the likely influence of these data on monetary policy.

This suggests that, if markets view the Beige Book as a signal of monetary policy, long-term rates might respond as much as or even more than short-term rates. Reports by the media are consistent with this hypothesis, with reports such as: "When the latest issue of the Beige Book was released just over a week ago ..., stock traders and other financial market participants decided the book's message was one of greater strength in the economy than they had been expecting. To the markets, that meant that the Fed was not likely to seek lower interest rates any time soon, and the traders' actions sent long-term rates up and bond prices down" (Berry 1988).

As noted above, this study is related to the literature on the effect of macroeconomic data releases on financial markets. Previous studies have reached mixed conclusions about the influence of such data as inflation, industrial production, and unemployment on stock prices (Cutler, Poterba, and Summers 1989; Flannery and Protopapadakis 2002; Hardouvelis 1987; Pearce and Roley 1985). ${ }^{6}$ There is more of a consensus that macroeconomic news releases move bond markets (Balduzzi, Elton, and Green 2001; Fleming and Remolona 1999). The Beige Book may similarly affect financial markets if it is viewed in the same vein as other macroeconomic news.

\section{Data and Methods}

This analysis examines Treasury constant-maturity yields and a broad index of stock prices. We focus on the 3-month, 6-month, and 1-year rates as measures of short-term interest rates and the 2year, 5-year, and 10-year rates as measures of intermediate and long-term yields; we also note results for several other points in the term structure. As in Flannery and Protopapadakis (2002), our measure of stock prices is the daily (close-to-close) value-weighted return in the NYSE, AMEX, and NASDAQ markets, without dividends. ${ }^{7}$ We examine daily changes in the interest rates (expressed in basis points) and the percentage change in the equity index. ${ }^{8}$

\footnotetext{
${ }^{6}$ Kohn and Sack (2003) conclude that FOMC statements, Congressional testimony, and speeches by Greenspan do not affect volatility in equity prices. They also note that comments specifically addressing asset valuations have not typically generated a response in asset prices.

${ }^{7}$ The interest rate data are from the H.15 release from the Board of Governors. The equity price index is from the Center for Research in Security Prices (CRSP) tapes.

${ }^{8}$ The analysis could also be performed intraday to check that any movements occur after the Beige Book is released. However, we do not know what time the pre-1990s Beige Books were released; the Beige Book is currently released at 2:15 p.m. Controlling for other major macroeconomic news releases (Table 5) reduces concerns about whether other news underlies the estimated relationships.
} 
Table 2. Descriptive Statistics

\begin{tabular}{lccrcc}
\hline & Mean & Std. Dev. & Max. & Min. & $\begin{array}{c}\text { Correlation with } \\
\text { Beige Book index }\end{array}$ \\
\hline Beige Book index & 0.659 & 0.456 & 1.5 & -1.0 & - \\
Daily change in: & & & & & \\
$\quad$ Treasury 3-month yield & -0.792 & 5.939 & 30.0 & -29.0 & 0.053 \\
Treasury 6-month yield & -1.007 & 4.964 & 14.0 & -23.0 & 0.150 \\
Treasury 1-year yield & -0.376 & 5.433 & 15.0 & -20.0 & 0.128 \\
Treasury 2-year yield & -0.342 & 5.809 & 20.0 & -19.0 & 0.152 \\
Treasury 5-year yield & -0.295 & 5.827 & 20.0 & -21.0 & 0.148 \\
Treasury 10-year yield & -0.054 & 4.840 & 18.0 & -16.0 & 0.192 \\
$\quad$ Value-weighted equity index & 0.109 & 0.975 & 8.7 & -2.1 & 0.106 \\
\hline
\end{tabular}

Shown are descriptive statistics for the Beige Book index and for the change in interest rates and equity prices on the day the Beige Book was released during the period May 1983 to December 2001. The changes in yields are expressed in basis points and the change in the equity index in percentage terms. The number of observations is 149 .

Table 2 reports descriptive statistics for our Beige Book index and the financial instrument variables. Although our Beige Book index was constructed on a range of -2 to 2 , in practice it ranges from -1 to 1.5. On average, interest rates declined on days when the Beige Book was released during our sample period, with an average change of less than 1 basis point for most of the yields we examine. The equity index rose an average of $0.1 \%$ on days when the Beige Book was released. As the table indicates, the 149 observations during the sample period encompass considerable variation in changes in yields and in the equity index.

The last column of Table 2 reports the simple correlation between the Beige Book index and the change in interest rates and the equity index on the day the report was released. During the sample period as a whole, the index is positively correlated with changes in short- and long-term interest rates and equity prices. The raw correlation is weakest for the change in 3-month t-bills and strongest for the 10-year bond.

We use a simple random walk model to further examine the relationship between the Beige Book and financial instruments. The random walk model posits that changes in interest rates and in equity prices are unpredictable, or

$$
\Delta y_{t}=\alpha+\beta B B_{t}+\varepsilon_{t} .
$$

We regress the daily change in our measures of interest rates and an equity index, $\Delta y_{t}$, on the Beige Book index, $B B_{t}$, and a constant. The coefficient on the Beige Book index variable captures the marginal effect of the Beige Book, and the constant captures the average effect. We focus on regressions that only use observations for days when the Beige Book was released; we discuss the robustness of the results if all days are included and if day-of-the-week effects are included in the model.

We estimate the regressions using ordinary least squares (OLS) and use the White method to correct the standard errors for heteroscedasticity. Our approach assumes that the full effect of the Beige Book - if any-on asset prices occurs the same day as it is released and that the Beige Book report is not anticipated by the market and already priced in. Ideally, we would estimate the effect of the unexpected component of the report, but quantitative market expectations are not available; we further address this issue below.

We treat the Beige Book scores as exogenous in the regressions because the reports are written based on observed economic activity as it has already occurred. Innovations in financial markets on 
Table 3. Relationship between Beige Book Index and Change in Financial Instruments

\begin{tabular}{lccccccc}
\hline & $\begin{array}{c}\text { 3-month } \\
(1)\end{array}$ & $\begin{array}{c}\text { 6-month } \\
(2)\end{array}$ & $\begin{array}{c}\text { 1-year } \\
(3)\end{array}$ & $\begin{array}{c}\text { 2-year } \\
(4)\end{array}$ & $\begin{array}{c}5 \text {-year } \\
(5)\end{array}$ & $\begin{array}{c}10 \text {-year } \\
(6)\end{array}$ & $\begin{array}{c}\text { Equities } \\
(7)\end{array}$ \\
\hline Beige Book & 0.685 & $1.636^{*}$ & $1.525^{*}$ & $1.941^{* *}$ & $1.897^{* *}$ & $2.393 * *$ & 0.227 \\
$\quad$ index & $(1.107)$ & $(0.832)$ & $(0.906)$ & $(0.917)$ & $(0.910)$ & $(0.997)$ & $(0.190)$ \\
Constant & -1.243 & $-2.085^{* * *}$ & $-1.381^{*}$ & $-1.621^{* *}$ & $-1.545^{* *}$ & $-1.966^{* *}$ & -0.041 \\
& $(0.024)$ & $(0.709)$ & $(0.772)$ & $(0.771)$ & $(0.765)$ & $(0.800)$ & $(0.126)$ \\
Adj. $R^{2}$ & 0.003 & 0.022 & 0.016 & 0.023 & 0.022 & 0.037 & 0.011 \\
$N$ & 149 & 149 & 149 & 149 & 149 & 149 & 149 \\
\hline
\end{tabular}

Shown are coefficients (standard errors) from OLS regressions in which the dependent variable is the daily change in the indicated variable (the percentage change for equities). Standard errors are White-corrected for heteroscedasticity.

$* p<0.10 ; * * p<0.05 ; * * * p<0.01$.

the day of the report's release cannot affect the information content of the document, which is written several days before it is released.

\section{Results}

The results indicate that the Beige Book index is positively associated with changes in most measures of interest rates during the period mid-1983 through 2001. Interpreting the results in Table 3 as marginal effects, a Beige Book with a score of 1 (which indicates strong growth) is associated with a 1.9 basis-point increase in the yield on the 2-year Treasury note and a 2.4 basis-point increase in the yield on the 10-year bond relative to a Beige Book with a score of 0 (neutral), for example. The estimated relationships tend to become slightly larger in magnitude and more statistically significant as maturity increases, although the increases in magnitude are not statistically significant. The Beige Book index is not significantly associated with changes in the 3-month t-bill rate (column 1) or with changes in 30-day federal funds rate futures or in the effective federal funds rate (not shown), but is associated with changes in the 6-month and 1-year rate at the $10 \%$ level and the 2-, 5-, and 10-year rate at the $5 \%$ level. ${ }^{9}$ The index is also positively and significantly associated with changes in the 30 -year rate (not shown).

We do not find a significant relationship between the Beige Book index and stock returns (column 6). This finding is consistent with Kohn and Sack's (2003) results for statements by the FOMC and by Greenspan and with the mixed results reported in the literature examining the effect of macroeconomic data releases.

The results in Table 3 are robust, including day-of-the-week fixed effects (not shown). We focus on results without day-of-the-week fixed effects because all Beige Books have been released on a Wednesday since mid-1988 and day-of-the-week fixed effects, therefore, might pick up time trends as well as any weekday effects. The results are also similar if we use all trading days, not just Beige Book release days, and include day-of-the-week dummy variables. Using observations for all trading days allows us to more precisely estimate the day-of-the-week effects but does not result in more efficient estimates of the Beige Book index coefficient because the report is not released on the other days.

Our finding that the Beige Book index appears to be more closely related to changes in intermediate- and long-term rates than with changes in overnight and short-term rates is rather

\footnotetext{
${ }^{9}$ All results discussed but not shown here are available from the authors on request. The data on the 30-day federal funds rate futures is available beginning in March 1989.
} 
puzzling at first glance. A simple version of the expectations hypothesis predicts that the Beige Book should have a greater impact, in both magnitude and statistical significance, on short-term rates because short-term rates are primarily based on expectations about monetary policy in the near future. However, short-term rates tend to be more variable than intermediate- and long-term rates (Kozicki and Tinsley 2001), making it more difficult to pick up any effect of the Beige Book on short-term rates. In addition, our results are consistent with those of Balduzzi, Elton, and Green (2001), who tend to find larger effects of macroeconomic data releases on long-term rates than on short-term rates. Our findings are also consistent with Campbell's (1995) observation that modest increases in short-term rates as a result of tightening by the FOMC can provoke large responses in long-term yields; if markets view stronger Beige Books as signaling upcoming tightening, there may be larger movements in longer-term yields than in short-term interest rates.

Another possibility is that traders may interpret the Beige Book as suggesting the direction of future changes in the federal funds rate target but not the explicit timing of such changes. In other words, a strong Beige Book might signal that the FOMC is likely to raise interest rates during the next few months but not necessarily at the next meeting; this would account for our finding that the relationship is significant for 6-month t-bills but not for 3-month t-bills, 30-day federal funds rate futures, or the effective federal funds rate. Our findings may also indicate that markets interpret stronger Beige Books as signaling future increases in inflationary pressures. A rise in the expected path of inflation would raise intermediate and long-term interest rates but have little effect on shortterm rates.

Finally, our results are consistent with Kohn and Sack's (2003) finding that Congressional testimony by Greenspan has a larger effect on intermediate-term rates than on short-term rates. FOMC statements, in contrast, primarily affect short-term rates, according to their analysis. Kohn and Sack speculate that this pattern occurs because Greenspan's comments tend to focus on the intermediateterm outlook for aggregate demand and on underlying fundamentals, such as productivity growth, while FOMC statements are more focused on the immediate path of monetary policy. Interpreting our results in their framework suggests that financial markets view the Beige Book as more of an indicator of the expected path of economic growth over the next few years than of monetary policy in the near term.

Consistent with this view, we do not find a significant positive relationship between our Beige Book index and changes in either the federal funds rate target set at the next FOMC meeting or the effective federal funds rate. Payne (2001), in contrast, does report such a relationship. The simple correlation between our index and Payne's index is 0.815 . Payne composed his scores by rating the adjectives used in the Beige Book summaries, including the District summaries; our measure is based on reading the entire national summary instead of just scoring the adjectives. Payne's scores are not significantly positively associated with any of the changes in interest rates, including the federal funds rate target, or in equity prices in our model. We do find a negative relationship between Payne's index and changes in the effective federal funds rate that is significant at the $10 \%$ level.

\section{Monetary Policy Regimes}

The effect of the Beige Book may depend on the direction of monetary policy. We classified monetary policy as tightening, easing, or constant, depending on the direction in which the FOMC changed the federal funds rate target at the meeting after each Beige Book was released. In results not shown here, there are no significant differences across monetary policy regimes in the relationship 
Table 4. Relationship between Beige Book Index and Change in Financial Instruments, by Transparency Regime

\begin{tabular}{lccccccc}
\hline & $\begin{array}{c}\text { 3-month } \\
(1)\end{array}$ & $\begin{array}{c}6 \text {-month } \\
(2)\end{array}$ & $\begin{array}{c}\text { 1-year } \\
(3)\end{array}$ & $\begin{array}{c}\text { 2-year } \\
(4)\end{array}$ & $\begin{array}{c}5 \text {-year } \\
(5)\end{array}$ & $\begin{array}{c}10 \text {-year } \\
(6)\end{array}$ & $\begin{array}{c}\text { Equities } \\
(7)\end{array}$ \\
\hline A. 1994-2001 & & & & & & & \\
Beige Book index & 2.513 & 2.624 & $2.997^{*}$ & $3.440^{* *}$ & $3.438^{* *}$ & $3.678^{*}$ & $0.637^{* *}$ \\
& $(2.026)$ & $(1.596)$ & $(1.644)$ & $(1.574)$ & $(1.338)$ & $(1.900)$ & $(0.251)$ \\
Constant & $-3.634^{*}$ & $-3.388^{* *}$ & $-3.537^{* *}$ & $-3.392^{* *}$ & $-3.374^{* *}$ & $-4.038^{* *}$ & $-0.487^{* *}$ \\
& $(1.944)$ & $(1.556)$ & $(1.611)$ & $(1.586)$ & $(1.291)$ & $(1.742)$ & $(0.213)$ \\
Adj. $R^{2}$ & 0.061 & 0.098 & 0.088 & 0.091 & 0.094 & 0.097 & 0.137 \\
$N$ & 63 & 63 & 63 & 63 & 63 & 63 & 63 \\
B. 1983-1994 & & & & & & & \\
Beige Book index & 0.001 & 1.275 & 1.170 & 1.218 & 1.161 & $2.242^{*}$ & -0.002 \\
& $(1.442)$ & $(1.124)$ & $(1.192)$ & $(1.281)$ & $(1.308)$ & $(1.164)$ & $(0.280)$ \\
Constant & $-0.152^{*}$ & $-1.492^{* *}$ & -0.444 & $-0.774 * *$ & -0.672 & -1.100 & 0.181 \\
& $(0.867)$ & $(0.683)$ & $(0.742)$ & $(0.766)$ & $(0.882)$ & $(0.750)$ & $(0.119)$ \\
Adj. $R^{2}$ & 0.000 & 0.010 & 0.007 & 0.007 & 0.006 & 0.028 & 0.000 \\
$N$ & 86 & 86 & 86 & 86 & 86 & 86 & 86 \\
\hline
\end{tabular}

Shown are coefficients (standard errors) from OLS regressions in which the dependent variable is the daily change in the indicated variable (the percentage change for equities). The regressions in panel A include data for Beige Books released between March 1994 and December 2001; panel B includes data for Beige Books released between May 1983 and February 1994. Standard errors are White-corrected for heteroscedasticity.

$* p<0.10 ; * * p<0.05 ; * * * p<0.01$.

between the Beige Book index and changes in financial instruments. ${ }^{10}$ We also investigated whether the results are different during the Greenspan era (which began in August 1987) than during the entire period mid-1983 through 2001. Results using only the period when Greenspan is chairman of the FOMC are similar to those shown in the tables.

The effect of the Beige Book may have changed over time as the FOMC made more information about monetary policy publicly available. Increased transparency by the FOMC might have reduced the value of the Beige Book as a signal of monetary policy, weakening the relationship between our index and changes in bond yields and stock returns. The results of dividing our sample into observations before and after the FOMC began announcing changes to the federal funds rate target on February 4, 1994, are shown in Table 4. The estimated coefficients on the Beige Book variable in the interest rate regressions for the post-transparency period (panel A) are similar to or larger in magnitude than the results for the full sample; whereas, the pretransparency period results (panel B) are generally insignificant and smaller in magnitude, albeit not significantly so. In addition, the Beige Book index is significantly positively associated with changes in the equity index during the post-transparency period. These results suggest that during the mid-1990s financial markets began viewing the Beige Book as a more useful signal of economic growth and future monetary policy moves at the same time the FOMC began making available more information about monetary policy making.

\footnotetext{
${ }^{10}$ We find that short- and intermediate-term interest rates (up to two years) fall when the FOMC lowers the target, but the effect does not change as the Beige Book index changes. Part of our failure to find that the effect of the Beige Book depends on the status of monetary policy may be because the FOMC ostensibly targeted borrowed reserves instead of the federal funds rate until late 1987. The data on the federal funds rate target are from the Federal Reserve Bank of New York, http://www. ny.frb.org/pihome/statistics/dlyrates/fedrate.html.
} 
Table 5. Relationship between Beige Book Index and Change in Financial Instruments, Controlling for Macroeconomic Data Release Days

\begin{tabular}{lccccccc}
\hline & $\begin{array}{c}\text { 3-month } \\
(1)\end{array}$ & $\begin{array}{c}6 \text {-month } \\
(2)\end{array}$ & $\begin{array}{c}\text { 1-year } \\
(3)\end{array}$ & $\begin{array}{c}2 \text {-year } \\
(4)\end{array}$ & $\begin{array}{c}5 \text {-year } \\
(5)\end{array}$ & $\begin{array}{c}10 \text {-year } \\
(6)\end{array}$ & $\begin{array}{c}\text { Equities } \\
(7)\end{array}$ \\
\hline Beige Book & 0.461 & $1.431^{*}$ & $1.403^{*}$ & $1.844^{* *}$ & $1.835^{* *}$ & $2.368^{* *}$ & 0.219 \\
$\quad$ index & $(1.075)$ & $(0.809)$ & $(0.860)$ & $(0.888)$ & $(0.872)$ & $(0.974)$ & $(0.187)$ \\
Unemployment & $-13.433^{* * *}$ & $-17.290^{* * *}$ & $-20.081^{* * *}$ & $-21.157^{* * *}$ & $-18.442^{* * *}$ & $-14.023^{* * *}$ & 0.444 \\
$\quad$ rate & $(3.428)$ & $(3.599)$ & $(4.113)$ & $(4.250)$ & $(4.366)$ & $(4.039)$ & $(0.424)$ \\
Industrial & $7.352^{* * *}$ & $6.590^{* * *}$ & $7.154^{* * *}$ & $6.642^{* * *}$ & $6.535^{* * *}$ & $5.132^{* * *}$ & 0.102 \\
$\quad$ production & $(2.336)$ & $(2.410)$ & $(2.307)$ & $(2.192)$ & $(2.141)$ & $(1.961)$ & $(0.219)$ \\
CPI & $6.959^{* *}$ & $8.629^{* * *}$ & $11.908^{* * *}$ & $10.914 * * *$ & $12.035^{* * *}$ & $10.485 * * *$ & $-1.688^{* *}$ \\
& $(3.388)$ & $(3.046)$ & $(3.577)$ & $(3.852)$ & $(4.142)$ & $(4.053)$ & $(0.679)$ \\
GDP & $1.098^{*}$ & $2.053^{* * *}$ & $2.603 * *$ & $2.465^{* *}$ & $2.001^{* *}$ & 1.383 & -0.014 \\
& $(0.663)$ & $(0.737)$ & $(1.011)$ & $(0.997)$ & $(1.005)$ & $(0.957)$ & $(0.099)$ \\
Adj. $R^{2}$ & 0.047 & 0.045 & 0.032 & 0.025 & 0.021 & 0.014 & 0.004 \\
$N$ & 4790 & 4790 & 4790 & 4790 & 4790 & 4790 & 4717 \\
\hline
\end{tabular}

Shown are coefficients (standard errors) from OLS regressions in which the dependent variable is the daily change in the indicated variable (the percentage change for equities). The non-Beige Book data releases are the difference between the actual release and the median forecast, as reported by MMS, and the regressions also include dummy variables indicating release days for each series, four day-of-the-week fixed effects and a constant. Standard errors are White-corrected for heteroscedasticity. $* p<0.10 ; * *<<0.05 ; * * * p<0.01$.

\section{Other Macroeconomic Data Releases}

As discussed above, a number of previous studies have concluded that macroeconomic data releases, such as the unemployment rate and the GDP growth rate, affect interest rates and stock prices. Some of these releases occurred on the same day as the Beige Book was released, creating the possibility that the regressions are picking up the effect of macroeconomic data releases. ${ }^{11} \mathrm{We}$, therefore, run the regressions with data on all days and include in the regressions the difference between the actual data release and the median forecast for several major macroeconomic indicators: the unemployment rate, industrial production, CPI, and GDP (or GNP) growth rate. ${ }^{12}$ We include only the unexpected component of these data releases in the regressions because asset prices are likely to already reflect the expected component.

The results for the Beige Book index are little affected by controlling for other major macroeconomic data releases in the regressions. As Table 5 shows, the Beige Book index remains significantly positively associated with the change in intermediate- and long-term rates, and the magnitudes of the coefficients on the Beige Book variable are similar to those in Table 3. However, the Beige Book generally has less of an impact (as measured by the magnitude and statistical significance of the coefficients) on interest rates than the other macroeconomic data releases examined here. For example, a one standard deviation increase in the Beige Book index is associated with an increase in the 2-year yield of about 0.84 basis points; a one standard deviation increase in the

\footnotetext{
${ }^{11}$ Five industrial production numbers, seven CPIs, and five GDP growth rates were released on the same day as the Beige Book during our sample period of May 1983 through December 2001.

12 The forecast data and the dates of the actual releases are from Money Market Services (MMS). Prior to 1990, the MMS tracked GNP instead of GDP. The regressions also include indicator variables for release days of each data series (including the Beige Book) and day-of-the-week fixed effects. The release date dummy variables are included for each series because the linear variables for the release data (less expectations for the unemployment rate, industrial production, CPI, and GDP data) equal zero on nonrelease days. These linear variables can also equal zero on release days; such zeroes contain information, unlike the zeroes for nonrelease days. Including dummy variables for release days controls for this.
} 
unexpected component of the unemployment rate, the industrial production index, CPI, and GDP growth rate is associated with a change of about $-3.51,1.73,1.33$, and 1.50 basis points, respectively, in the 2-year yield, all of which exceed that of the Beige Book index. ${ }^{13}$ In addition, unlike the Beige Book, the other data releases are significantly associated with movements in 3-month yields as well as longer-term interest rates. Only the CPI is significantly associated with changes in stock prices.

\section{Beige Book Expectations}

Unlike the macroeconomic data releases discussed above, there is no published measure of market participants' expectations about the Beige Book. This research, therefore, cannot directly measure the effect of the unexpected component of Beige Book scores on interest rates and equities. However, we can use several methods to approximate market expectations of the Beige Book. One cautionary note is that these approximations of market expectations are likely to contain considerable measurement error and, therefore, lead us to underestimate the true impact of the Beige Book on interest rates and equity prices.

One way to control for market expectations about the Beige Book is to use the difference between the current Beige Book score and the previous Beige Book score in the regressions instead of the linear Beige Book index variable. In results not shown here, the change in the Beige Book score is generally not significantly associated with changes in interest rates or in equity prices, suggesting that innovations in the report do not affect financial instruments. Another means of controlling for market expectations is to include separate variables for the current and the previous Beige Book scores in the regressions. When we do this, neither the current nor the lagged Beige Book score is individually significantly positively associated with changes in yields or in equity prices. However, the two variables are highly collinear $(\rho=0.82)$ and are jointly significantly associated with the change in the 2-, 5-, and 10-year yield.

We also examine the effect of controlling for the level of economic activity indicated by the most recent macroeconomic data available when the Beige Book was released. Other measures of the current (or recent) level of economic activity may capture market expectations of the Beige Book. In addition, controlling for other key data releases allows us to evaluate whether the Beige Book is viewed as an independent indicator of the state of the economy or the future direction of monetary policy. If the estimated coefficient of the Beige Book index variable falls in magnitude and significance when other indicators are controlled for, it may indicate that financial markets view the Beige Book as a synopsis of what is available in other data series. On the other hand, to the extent that the Beige Book is well correlated with economic activity, as indicated in Table 1, controlling for other data series may lead to multicollinearity problems and cause us to underestimate the true impact of the Beige Book on financial markets. We examine this by including the current release of the unemployment rate, industrial production index, CPI, and GDP growth rate on the right-hand side of our basic regression model. ${ }^{14}$ The results are shown in Table 6 .

Controlling for other macroeconomic indicators substantially reduces the magnitude of the coefficients on the Beige Book index and renders them statistically insignificant. Nevertheless, the general pattern of the coefficients is similar to our earlier results, with the magnitude of the estimated relationship between the Beige Book index and interest rates increasing with maturity. The results

\footnotetext{
${ }^{13}$ The standard deviations of the differences between the actual and expected unemployment rate, industrial production index, CPI, and GDP growth rates are $0.166,0.261,0.122$, and 0.609 , respectively.

${ }^{14}$ If a macroeconomic data release occurs on the same day as the Beige Book, we use the previous release of the data series in these regressions. The regressions are estimated only for Beige Book release days.
} 
Table 6. Relationship between Beige Book Index and Change in Financial Instruments, Controlling for Most Recent Available Macroeconomic Data

\begin{tabular}{lccccccc}
\hline & $\begin{array}{c}\text { 3-month } \\
(1)\end{array}$ & $\begin{array}{c}6 \text {-month } \\
(2)\end{array}$ & $\begin{array}{c}\text { 1-year } \\
(3)\end{array}$ & $\begin{array}{c}\text { 2-year } \\
(4)\end{array}$ & $\begin{array}{c}5 \text {-year } \\
(5)\end{array}$ & $\begin{array}{c}10 \text {-year } \\
(6)\end{array}$ & $\begin{array}{c}\text { Equities } \\
(7)\end{array}$ \\
\hline Beige Book index & -0.829 & 0.976 & 0.122 & 0.115 & 0.924 & 1.521 & 0.292 \\
& $(1.332)$ & $(0.943)$ & $(1.036)$ & $(1.100)$ & $(1.137)$ & $(1.220)$ & $(0.270)$ \\
Unemployment rate & 0.324 & -0.112 & 0.034 & 0.044 & 0.020 & 0.262 & 0.013 \\
& $(0.316)$ & $(0.308)$ & $(4.113)$ & $(0.335)$ & $(0.377)$ & $(0.374)$ & $(0.049)$ \\
Industrial production & 0.601 & 0.939 & 1.673 & 1.548 & 1.127 & 1.213 & -0.011 \\
& $(1.066)$ & $(0.907)$ & $(1.145)$ & $(1.148)$ & $(1.177)$ & $(1.027)$ & $(0.118)$ \\
CPI & -0.374 & 0.188 & -0.474 & -2.747 & -0.549 & -1.245 & 0.486 \\
& $(2.531)$ & $(2.043)$ & $(2.305)$ & $(2.420)$ & $(2.315)$ & $(2.194)$ & $(0.519)$ \\
GDP & $0.490 *$ & 0.088 & 0.219 & 0.345 & 0.152 & 0.060 & -0.009 \\
& $(0.249)$ & $(0.255)$ & $(0.275)$ & $(0.260)$ & $(0.271)$ & $(0.275)$ & $(0.044)$ \\
Adj. $R^{2}$ & 0.035 & 0.032 & 0.046 & 0.063 & 0.034 & 0.055 & 0.021 \\
$N$ & 149 & 149 & 149 & 149 & 149 & 149 & 149 \\
\hline
\end{tabular}

Shown are coefficients (standard errors) from OLS regressions in which the dependent variable is the daily change in the indicated variable (the percentage change for equities). The non-Beige Book data releases are the most recent available data point for each series, and the regressions also include a constant. Standard errors are White-corrected for heteroscedasticity.

$* p<0.10 ; * * p<0.05$; *** $p<0.01$.

suggest that market participants view the Beige Book as not having additional explanatory value after conditioning on macroeconomic data already available. However, we caution that these results are imprecisely estimated, making it difficult to draw strong conclusions. We note that it is not surprising that almost none of the coefficients on the macroeconomic data indicators are significantly associated with changes in financial instruments on the day the Beige Book was released since these data were already available. Including either the GDP growth rate or the change in the industrial production index is sufficient to make the Beige Book index variable statistically insignificant, but the results are similar to those in Table 3 if only the unemployment rate or the inflation rate is included (not shown).

It is important to note that controlling for the current level of economic activity may cause us to underestimate the Beige Book coefficient for a reason other than measurement error. As shown in Table 1, the Beige Book is highly correlated with GDP growth. This multicollinearity between GDP growth and the Beige Book index would reduce our estimates of the impact of the Beige Book on financial markets. Although the Beige Book is no longer statistically significant after controlling for other economic indicators, it does have a significant impact in our more parsimonious specifications (Tables 3-5), suggesting that the reports contain some information that is new to financial markets. Thus, we interpret the results in Table 6 as suggesting that the Beige Book is viewed as an indicator of economic activity and not of monetary policy moves in the near term.

\section{Conclusion}

This study examines the relationship between changes in financial instruments and the qualitative report on economic activity released by the Federal Reserve System in advance of FOMC meetings. Results that do not condition on other publicly available measures of economic activity suggest that markets respond to qualitative information released by the Federal Reserve System; a quantitative index of the Beige Book is positively associated with changes in intermediate- and longterm interest rates on Treasury securities but is not significantly associated with changes in overnight 
and 3-month rates or in equity prices during the period mid-1983-2001 as a whole. The Beige Book is significantly associated with changes in interest rates when conditioning on available information about recent inflation and unemployment but not when controlling for several other measures of recent economic activity. As a whole, our results indicate that financial markets view the Beige Book as providing information about economic activity but not as a signal of monetary policy in the short run.

\section{References}

Andersen, Torben G., Tim Bollerslev, Francis X. Diebold, and Clara Vega. 2003. Micro effects of macro announcements. American Economic Review 93:38-62.

Balduzzi, Pierluigi, Giuseppe Bertola, and Silverio Foresi. 1997. A model of target changes and the term structure of interest rates. Journal of Monetary Economics 391:223-49.

Balduzzi, Pierluigi, Edwin J. Elton, and T. Clifton Green. 2001. Economic news and bond prices. Journal of Financial and Quantitative Analysis 36:523-43.

Balke, Nathan S., and D'Ann Petersen. 2002. How well does the Beige Book reflect economic activity? Evaluating qualitative information quantitatively. Journal of Money, Credit, and Banking 34:114-36.

Balke, Nathan, and Mine K. Yucel. 2000. Evaluating the Eleventh District's Beige Book. Federal Reserve Bank of Dallas. Economic and Financial Review:2-10.

Bauman, Larry. 1995. Russell 2000 retreats after release of Beige Book, ends with modest gains. Wall Street Journal, 14 September, p. C7.

Berry, John M. 1988. Fed Governors' "Beige Book" paints rosier picture of the economy. Washington Post, 27 March, p. H2.

Berry, Thomas D., and Keith M. Howe. 1994. Public information arrival. Journal of Finance 49:1331-46.

Campbell, John Y. 1995. Some lessons from the yield curve. Journal of Economic Perspectives 9:29-152.

Cutler, David M., James M. Poterba, and Lawrence H. Summers. 1989. What moves stock prices? Journal of Portfolio Management 15:4-12.

Fettig, David, Arthur J. Rolnick, and David E. Runkle. 1999. The Federal Reserve's Beige Book: A better mirror than crystal ball. Federal Reserve Bank of Minneapolis. The Region 28-32.

Flannery, Mark J., and Aris A. Protopapadakis. 2002. Macroeconomic factors do influence aggregate stock returns. Review of Financial Studies 15:751-82.

Fleming, Michael J., and Eli M. Remolona. 1999. Price formation and liquidity in the U.S. Treasury market. Journal of Finance 54:1901-15.

Ginther, Donna K., and Madeline Zavodny. 2001. The Sixth District Beige Book: Timely information on the regional economy. Federal Reserve Bank of Atlanta. Economic Review 86:19-29.

Greenspan, Alan. 1994. Testimony before the Committee on Banking, Housing, and Urban Affairs, U.S. Senate, July 20.

Hardouvelis, Gikas A. 1987. Macroeconomic information and stock prices. Journal of Economics and Business 39:131-40.

Hurtado, Robert. 1994. Bond prices are lifted by the Fed's Beige Book. New York Times, 10 March, p. D16.

Kohn, Donald L., and Brian P. Sack. 2003. Central bank talk: Does it matter and why? Unpublished paper, Board of Governors of the Federal Reserve System.

Kozicki, Sharon, and Peter A. Tinsley. 2001. What do you expect? Imperfect policy credibility and tests of the expectations hypothesis. Federal Reserve Bank of Kansas City Working Paper No. RWP 01-02.

Kuttner, Kenneth N. 2001. Monetary policy surprises and interest rates. Journal of Monetary Economics 47:523-44.

McQueen, Grant, and V. Vance Roley. 1993. Stock prices, news, and business conditions. Review of Financial Studies 6: 683-707.

McTague, Jim. 1991. The Beige Book: Overrated, but widely awaited anyway. American Banker, 17 June, p. 10.

Mitchell, Mark L., and J. Harold Mulherin. 1994. The impact of public information on the stock market. Journal of Finance 49:923-50.

Payne, David R. 2001. Anticipating monetary policy with the Federal Reserve's Beige Book: Re-specifying the Taylor rule. Business Economics 36:21-30.

Pearce, Douglas K., and V. Vance. 1985. Stock prices and economic news. Journal of Business 58:49-67. 